\title{
Adventitious plants of the flora of the city of Omsk
}

\author{
Maria Antipova $^{1 *}$, and Galina Samoylova ${ }^{2}$ \\ ${ }^{1}$ Omsk State Medical University, 644099 Omsk, Russia \\ ${ }^{2}$ Omsk State Pedagogical University, 644043 Omsk, Russia
}

\begin{abstract}
The data of the study and analysis of the adventive element of the flora of the city of Omsk are presented. The updated list of adventitious plants of the flora of the city of Omsk is given. The invasive plants listed in the Black Book of Siberia are indicated.
\end{abstract}

Synanthropization is a characteristic feature of the modern development of the vegetation cover of anthropogenically transformed territories. It allows adventitious (introduced) species to penetrate into the local flora. Many adventitious plants, spreading both with the conscious and unconscious participation of a person, are capable of naturalization, becoming permanent components of the vegetation cover of urbanized territories. The study of the process of replenishing the flora with adventitious plants is one of the elements of biomonitoring of the state of the environment.

Omsk, being one of the oldest cities in Western Siberia, currently includes 5 administrative districts with different ages and different degrees of urbanization, and is a combination of man-made and biogenic landscapes. The city continues to grow in three directions along the banks of the Om and Irtysh rivers. The last decade has been marked by an increase in the density of its development and the degree of improvement, while in the modern layout of residential quarters, a significant part of the area is allocated for landscaping. The modern area of the city is more than $572 \mathrm{~km}^{2}$. The branch of the West Siberian Railway, the developed river shipping company, and air communication made Omsk a major transport and distribution center.

The surroundings of the regional center have almost no natural forests. Forest vegetation, concentrated mainly on the urban outskirts, is mainly secondary, the dominant among woody plants are Betula pendula, Populus tremula. The remains of a natural pine forest are located on the right-bank part of the city. Areas of natural meadow and steppe vegetation are preserved in urban recreational areas. Willow-poplar and shrub communities are characteristic of the floodplain and islands along the river banks. Saline habitats in the urban area determine the presence of cenoses of halophytes [1].

The main floristic studies of adventitious plants of the flora of the city of Omsk were conducted in the period from 2000 to 2003, followed by monitoring in 2018-2020 by the traditional route method, allowed to register 147 adventitious species, which amounted to $21.3 \%$ of the total flora of the city of Omsk. The novelties of monitoring studies in 2018-

* Corresponding author: antipm@list.ru 
2020 were Sagina procumbens L., Chorispora tenella (Pall.) DC., R. brachycarpa (C. A. Mey.) Hayek, Acalypha australis L., Veronica biloba Schreb., V. filiformis Sm., Tragopogon podolicus (DC.) S. A. Nikitin, Eremopyrum triticeum (Gaertn.) Nevski., Lotus sorniculatus $L$.

Advents systematically belong to 107 genera and 41 families of angiosperms, most of which are dicotyledonous plants $(94 \%)$. The most abundant alien species are the following families: Asteraceae (24 species), Brassicaceae (16 species), Chenopodiaceae (15 species), Fabaceae (10 species), Poaceae (8 species).

The analysis of the ecological spectrum showed that adventitious species have the opportunity to develop a variety of biotopes in the study area and are represented by various ecological groups. A significant percentage of mesophytes (more than $50 \%$ ) indicates the prevalence of substrates with moderate moisture. At the same time, the alien xerophytes and mesoxerophytes, which together contain almost $1 / 3$ of the total composition of advents, confirm the trend of xerophitization of urbanized territories. In addition, 13 species were identified that can grow in populated habitats (halophytes).

Table 1. Ecological spectrum by moisture factor

\begin{tabular}{|l|c|c|}
\hline $\begin{array}{c}\text { Environmental } \\
\text { Group }\end{array}$ & $\begin{array}{c}\text { number of } \\
\text { species }\end{array}$ & $\begin{array}{c}\% \text { of the total } \\
\text { number }\end{array}$ \\
\hline Mesophytes & 82 & 55,7 \\
\hline Mesoxerophytes & 41 & 27,9 \\
\hline Xerophytes & 9 & 6,1 \\
\hline Mesohygrophytes & 12 & 8,2 \\
\hline Hygrophytes & 2 & 1,4 \\
\hline Hydrophytes & 1 & 0,7 \\
\hline Total: & 147 & 100 \\
\hline
\end{tabular}

When analyzing the biomorphs of the studied plants according to the classification of K. Raunkier, it turned out that most of them are herbaceous plants with a short life cycle (annual plants), which is a indication of a long and intensive anthropogenic influence on the vegetation cover of the studied territory.

Table 2. Composition of life forms

\begin{tabular}{|l|c|c|}
\hline \multicolumn{1}{|c|}{ Life forms } & $\begin{array}{c}\text { number of } \\
\text { species }\end{array}$ & $\begin{array}{c}\% \text { of the total } \\
\text { number }\end{array}$ \\
\hline Phanerophytes & 10 & 6,8 \\
\hline $\begin{array}{l}\text { Hemicryptophyte } \\
\text { s }\end{array}$ & 42 & 28,6 \\
\hline $\begin{array}{l}\text { Cryptophytes } \\
\text { Including: } \\
\text { Geophytes } \\
\text { Hydrophytes }\end{array}$ & 4 & \\
\hline Therophytes & 89 & 2,7 \\
\hline Total: & 147 & 60,5 \\
\hline
\end{tabular}


The geographical analysis of the advent element, carried out by types of habitats and indicating the main ways of plant migration to the studied territory, revealed that the flora of the city of Omsk is actively replenished due to species whose range covers the territories of Europe and Asia, and the northern hemisphere as a whole. The location of the regional center and the developed transport network contributes to the links with the flora of Central Asia, Kazakhstan, and Central Asia. Thanks to the species that escaped their natural habitat, the European group itself is enriched and the American group appears. In general, synanthropization helps to strengthen the positions of broad-area species in the flora.

Table 3. The ratio of geographical groups

\begin{tabular}{|l|c|c|}
\hline \multicolumn{1}{|c|}{$\begin{array}{c}\text { Geographical } \\
\text { group }\end{array}$} & $\begin{array}{c}\text { number of } \\
\text { species }\end{array}$ & $\begin{array}{c}\text { \% of the total } \\
\text { number }\end{array}$ \\
\hline Cosmopolitan & 16 & 10,9 \\
\hline Holarctic & 28 & 19,0 \\
\hline Eurasian & 72 & 49 \\
\hline Asian: & 12 & 8,2 \\
Actually Asian & 1 & 0,7 \\
Turan-East Asian & & \\
\hline European: & 8 & 5,4 \\
Actually & 1 & 0,7 \\
European & & 5,4 \\
Eastern European & 8 & 0,7 \\
\hline American: & 1 & 100 \\
North American & 147 & \\
South American & & \\
\hline Total: & & \\
\hline
\end{tabular}

Traditionally, when analyzing adventitious plants, they are distinguished by the time of introduction, the method of introduction, as well as the degree of naturalization [2].

In the course of the analysis of the advent component of the flora of Omsk, classifications based on two criteria were used - the method of introduction and the degree of naturalization, which allow to identify the role of a person in the process of transferring advent trees to new territories, and the level of their adaptation to new geographical conditions.

To identify the method of introduction, classification groups that were applied for the study of the adventitious flora of the Voronezh region: xenophytes - immigrants who spontaneously appeared on the studied territory as a result of transcontinental, transzonal and interzonal transfer due to human activity; ergaziolipophytes - introduced species, planted in natural conditions or on natural-anthropogenic habitats and growing there without human care; ergaziophygophytes - introduced species, leaving the places of culture $[2,3]$.

To determine the degree of naturalization, a more compact version of the classification of the authors of the adventive flora of the Voronezh region was used: ephemerophytes fluctuating species that appear and disappear in local habitats, colonophytes-species that are firmly entrenched in new habitats, but do not spread from them, epecophytes - alien species that settle in disturbed habitats (species of ruderal communities). At the same time, the proposed group of agriophytes was not distinguished by us, since the natural vegetation cover on the territory we studied was practically not preserved. 
Table 4. Distribution of species of adventitious plants by the method of introduction and the degree of naturalization

\begin{tabular}{|c|c|c|}
\hline Classification groups & $\begin{array}{c}\text { number of } \\
\text { species }\end{array}$ & $\begin{array}{c}\% \text { in the } \\
\text { group }\end{array}$ \\
\hline \multicolumn{2}{|c|}{ Method of introduction of adventitious species } \\
\hline Xenophytes & 116 & 79 \\
\hline Ergaziolipophytes & 8 & 5,4 \\
\hline Ergasiophygophytes & 23 & 15,6 \\
\hline Degree of naturalization of adventitious species \\
\hline Ephemerophytes & 58 & 39,5 \\
\hline Colonophytes & 28 & 19,0 \\
\hline Epecophytes & 61 & 41,5 \\
\hline
\end{tabular}

According to the method of introduction, xenophytes are leading - $79 \%$ of the total number of advents, which is due to various options of transport communication of the city of Omsk with various regions of the country, as well as Kazakhstan. Ergaziolipophytes are represented by woody plants that have been successfully introduced, are actively used in landscaping, give good self-seeding and do not require attention. The group of ergasiophygophytes was formed mainly by herbaceous unpretentious plants grown as food and ornamental, capable of easily leaving the culture.

The analysis of adventitious plants of the flora of the city of Omsk by the degree of naturalization revealed a significant percentage of alien species that are quite successfully mastered and fixed in the new territory, and make up groups of colonophytes and epecophytes. The resulting total result of $89 \%$ indicates the successful naturalization of most of the advent, which emphasizes the anthropogenic transformation of the flora of the city of Omsk.

List of adventitious plants of the flora of Omsk.

Poaceae: Avena fatua L., A. sativa L., Echinochloa crusgalli (L.) Beauv., Eremopyrum triticeum (Gaertn.) Nevski, Hordeum jubatum L., Puccinellia hauptiana Krecz., Setaria viridis (L.) Beauv., Triticum aеstivum Невский

Cyperaceae: Scirpus ehrenbergii Boeck.

Commelinaceae: Commelina communis L.

Fagaceae: Quercus robur L.

Ulmaceae:Ulmus laevis Pall., U. pumila L.

Cannabaceae: Cannabis sativa $L$.

Urticaceae: Urtica cannabina L., U. urens $L$.

Polygonaceae: Fallopia convolvulus (L.) A. Löve

Chenopodiaceae: Atriplex hortensis L., A. prostrata Boucher ex DC, A. sagittata Borkh., A. tatarica L., Axyris maranthoides L., Chenopodium aristatum L., Ch. ficifolium Smith, Ch. glaucum L., Ch. hybridum L., Ch. opulifolium Schrader, Ch. polyspermum L., Ch. rubrum L., Ch. urbicum L., Kochia densiflora (Moq.) Aell., Salsola collina Pallas

Amaranthaceae: Amaranthus retroflexus L. A. albus $L$. 
Portulacaceae: Portulaca oleracea L.

Caryophyllaceae: Gypsophila perfoliata L., Saponaria officinalis L., Sagina procumbens $L$.

Ranunculaceae: Aquilegia vulgaris L., Consolida regalis S. F. Gray., Halerpestes salsuginosa (Pallas ex Georgi) Greene

Papaveraceae: Chelidonium majus L.

Brassicaceae: Armoracia rusticana Gaertner, Meyer et Scherber, Brassica campestris L., B. napus L., Bunias orientalis L., Cardaria draba (L) Desv., Descurainia sophia (L.) Webb ex Prantl, Chorispora tenella (Pall.) DC., Lepidium latifolium L., Raphanus raphanistrum L., Rorippa sylvestris (L.) Besser, R. brachycarpa (C.A. Mey.) Hayek, Sinapis alba L., S. arvensis L., Sisymbrium altissimum L., S. loeselii L., S. officinale (L.) Scop.

Crassulaceae: Sedum acre $L$.

Rosaceae: Malus baccata (L.) Borkh., Amelanchier spicata (Lam.) K. Koch

Fabaceae: Halimodendron halodendron (Pallas) Voss, Lotus corniculatus L., Lupinus polyphyllus Lindley, Medicago sativa L., Melilotus officinalis (L.) Pallas, Onobrychis arenaria (Kit.) DC., Trifolium hybridum L., Vicia biennis L., V. hirsuta (L.) S. F. Gray, V. sativa $L$.

Geraniaceae: Erodium cicutarium (L.) L'Her.

Euphorbiaceae: Euphorbia humifusa Willd., E. virgata Waldst. et Kit., Acalypha australis $L$.

Aceraceae: Acer negundo

Balsaminaceae: Impatiens balsamina L. 77

Malvaceae: Alcea rosea L. Lavatera thuringiaca L., Malva crispa (L.) L., M. mauritiana L., M. mohileviensis Downar., M. pusilla Smith.

Violaceae: Viola arvensis Murray, V. tricolor L. $L$.

Elaeagnaceae: Elaeagnus argentea Pursch, E. angustifolia L., Hippophae rhamnoides

Onagraceae: Oenothera biennis L., O. villosa Thunb.

Apiaceae: Anethum graveolens L., Conium maculatum L., Pastinaca sativa L.

Gentianaceae: Centaureum pulchellum (Sw.) Druce.

Cuscutaceae: Cuscuta europaea L.

Hydrophyllaceae: Phacelia tanacetifolia Bentham

Boraginaceae: Asperugo procumbens L., Borago officinalis L., Buglossoides arvensis (L.) Johnston Moench., Echium vulgare L., Lappula consanguinea (Fischer et C. A. Meyer) Guerke, Lycopsis arvensis L., Symphytum officinale L.

Lamiaceae: Chaiturus marrubiastrum (L.) Ehrh. Ex Reichenb., Dracocephalum nutans L., Elsholtzia ciliata (Thunb.) Hyl., Galeopsis bifida Boenn., G. ladanum L., Lamium amplexicaule $L$.

Solanaceae: Datura stramonium L., Hyoscyamus niger L. Solanum cornutum Lam., S. nigrum L., S. triflorum Nutt.

Scrophulariaceae: Veronica biloba Schreb., V. filiformis Sm.

Plantaginaceae: Plantago lanceolata L.

Rubiaceae: Galium vaillantii DC.

Valerianaceae: Valeriana officinalis $L$.

Dipsacaceae: Knautia arvensis (L.) Coulter 120

Cucurbitaceae: Echinocystis lobata (Michx.) Torr. et Gray, Thladiantha dubia Bunge

Asteraceae: Anthemis subtinctoria Dobrocz., Calendula officinalis L., Centaurea cyanus L., C. pseudomaculosa Dobrocz., Chamomilla recutita (L.) Rauschert, Ch. suaveolens (Pursh) Rydb., Cichorium intybus L., Cosmos bipinnatus Cav., Echinops phaerocephalus L., Erigeron annuus (L.) Pers., E canadensis L., Galinsoga parviflora Cav., Helianthus annuus L., H. tuberosus L., Lactuca sativa L., L. serriola L., L. tatarica 
(L.) C. A. Meyer, Matricaria perforata Merat, Senecio vulgaris L., Solidago canadensis L., Sonchus asper (L.) Hill, S. oleraceus L., Tragopogon podolicus (DC.) S.A. Nikitin, Xanthium strumarium L.

Hydrocharitaceae: Elodea canadensis Michx.

38 adventitious species from the above list are included in the Black Book of the Flora of Siberia, are classified as invasive and can pose an ecological and economic danger to Siberia. Among them are: Echinochloa crusgalli (L.) Beauv., Hordeum jubatum L., Ulmus laevis Pall., U. pumila L., Atriplex sagittata Borkh., Amaranthus retroflexus L., Saponaria officinalis L., Armoracia rusticana Gaertner, Meyer et Scherber, Rorippa sylvestris (L.) Besser, Sisymbrium officinale (L.) Scop., Lotus corniculatus L., Lupinus polyphyllus Lindley, Medicago sativa L., Melilotus officinalis (L.) Pallas, Vicia hirsuta (L.) S. F. Gray, Trifolium hybridum L., Acer negundo L., Elaeagnus angustifolia L., Oenothera villosa Thunb., Conium maculatum L., Pastinaca sativa L., Cuscuta europaea L., Echium vulgare L., Elsholtzia ciliata (Thunb.) Hyl., Solanum triflorum Nutt., Plantago lanceolata L., Echinocystis lobata (Michx.) Torr. et Gray, Centaurea pseudomaculosa Dobrocz., Chamomilla suaveolens (Pursh) Rydb., Erigeron canadensis L., Helianthus tuberosus L., Lactuca serriola L., Matricaria perforata Merat, Senecio vulgaris L., Solidago canadensis L., Xanthium strumarium L., Elodea canadensis Michx., Amelanchier spicata (Lam.) K. Koch [4].

Thus, in such a large industrial city as Omsk, which has a developed transport network, modern trends in the development of urban flora are quite clearly manifested. Adventitious species become an integral component of urban flora, the share of which is determined by both natural and social factors.

\section{References}

1. M. G. Budanova, Flora of vascular plants of the city of Omsk (Tomsk, 2003)

2. D. R. Vladimirov, Tu Weigo, Bulletin of Voronezh State University, Geography series. Geoecology, 3 (2016)

3. A. Ya. Grigoryevskaya et al., Adventive flora of the Voronezh region: historical, biogeographic, ecological aspects, (Voronezh, Voronezh University Press, 2004)

4. The Black Book of the flora of Siberia (Novosibirsk, Geo, 2016) 